\title{
TREND RISET NEUROPEDAGOGI DAN IMPLEMENTASINYA DALAM PENDIDIKAN
}

\author{
Neneng Maryam Jamaliah Nurul Janah ${ }^{1}$, Asep Supena ${ }^{2}$ \\ ${ }^{1,2}$ Universitas Negeri Jakarta
}

\begin{abstract}
This article aims to review the development of neuropedagogy research and its implementation in education. The method of writing this article is to use literature study (literature review). In this study twenty articles were chosen between the years 2016-2019 taken from google scholars' sources on the topic of neuropedagogy in education. Research on neuropedagogy has experienced significant developments, various scientific fields have sought to integrate neuropedagogy as an approach, technique and learning method to optimize student performance in learning. Various levels of education starting at the level of early childhood education until students have become the target of a neuropedagogical approach, but research on the implementation of neuropedagogy at the elementary school level has not been much researched. This is what underlies the authors to conduct a review of neuropedagogical research trends, so that it becomes a recommendation for further follow-up research, especially in the field of basic education.
\end{abstract}

Keyword: Neuropedagogy, Education, Research

\begin{abstract}
Abstrak: Artikel ini bertujuan untuk mereview perkembangan penelitian neuropedagogy dan implementasinya dalam pendidikan. Metode penulisan artikel ini adalah menggunakan studi pustaka (literature review). Dalam penelitian ini dipilih sebanyak dua puluh artikel antara tahun 2016-2019 yang diambil dari sumber google scholars mengenai topik neuropedagogi dalam pendidikan. Penelitian mengenai neuropedagogi telah mengalami perkembangan yang cukup signifikan, berbagai bidang keilmuan telah berupaya mengintegrasikan neuropedagogi sebagai sebuah pendekatan, teknik dan metode pembelajaran guna mengoptimalkan performa peserta didik dalam belajar. Berbagai jenjang pendidikan dimulai tingkat pendidikan usia dini hingga mahasiswa telah menjadi sasaran pendekatan neuropedagogi, namun penelitian tentang implementasi neuropedagogi pada jenjang sekolah dasar belum banyak diteliti. Hal inilah yang mendasari penulis untuk melakukan review terhadap trend penelitian neuropedagogi, agar menjadi rekomendasi tindak lanjut penelitian berikutnya, khususnya di bidang pendidikan dasar.
\end{abstract}

Kata Kunci: Neuropedagogi, Pendidikan, Riset

\footnotetext{
' Universitas Negeri Jakarta, Email: neneng.maryam|408回gmail.com

${ }^{2}$ Universitas Negeri Jakarta, Email: supena20079 @yahou.cum
} 
PENDAHULUAN

Neuropedagogi adalah kajian interdisipliner yang menggabungkan tiga bidang ilmu yaang telah ada dan berkembang sebelumnya, yaitu bidang kajian psikologi, neurosains dan pendidikan. (Chojak, 2018). Neuropedagogi dapat didefinisikan sebagai bidang ilmu sosial dan termasuk disiplin ilmu yang berkaitan dengan perkembangan dan perubahan dalam mekanisme pendidikan di seluruh kehidupan manusia.

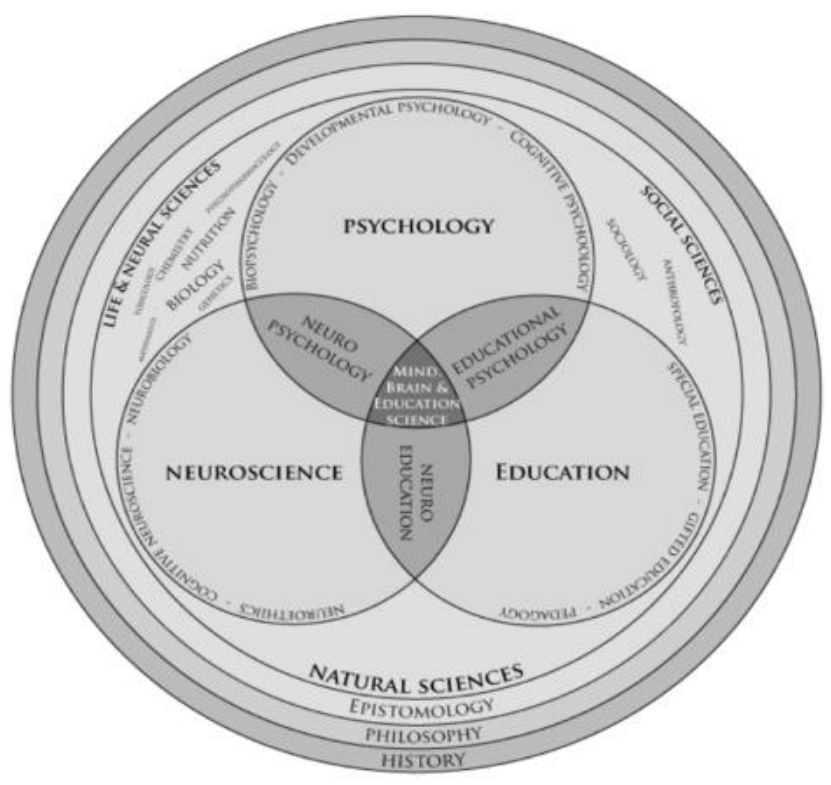

Gambar 1. Diagram interdisiplin kajian neuropedagogi. Sumber: Chojak (2018)

Neuropedagogis bertujuan untuk menciptakan peningkatan pembelajaran melalui inisiatif pendidik untuk menggunakan penemuan tentang belajar, memori, bahasa, dan daerah lain dalam struktur kognitif siswa, sehingga pendidik dapat menciptakan strategi terbaik untuk mengajar dan belajar. Dengan demikian, tugas-tugas neuropedagogi harus mencakup: (i) Mengumpulkan informasi tentang kondisi neurobiologis dari realitas pendidikan; (ii) Analisis realitas, hubungan dan ketergantungan di dalamnya; (3) menyebarkan pengetahuan yang diperoleh untuk tujuan transformasi realitas seperti itu.

Studi penelitian tentang perkembangan otak dan perkembangan emosional anak-anak menunjukkan pentingnya tahun-tahun awal dalam pertumbuhan dan perkembangan anak dan kehidupan mereka di masa depan (Bergen dan Woodin, 2017). Saat itu temuan penelitian terkait dengan perkembangan otak dan emosi anak terintegrasi dengan masalah-masalah penting pedagogi, suatu keilmuandialog antara guru kelas dan ahli saraf diharapkan muncul dengan niat mengeksplorasi kemungkinan untuk memulai arah baru dalam pedagogi (Nouri, 2016).

\section{METODOLOGI PENELITIAN}

Penulisan artikel ini menggunakan pendekatan studi pustaka (literature review). Literature review bertujuan untuk mengidentifikasi, menilai, dan menginterpretasi seluruh temuan-temuan pada suatu topik penelitian, untuk menjawab pertanyaan penelitian (research question) yang telah ditetapkan sebelumnya (Kitchenham \& Charters, 2007). Dalam penelitian ini dipilih sebanyak dua puluh artikel antara tahun 2015-2019 yang diambil dari sumber google scholars mengenai topik neuropedagogi dalam pendidikan.

\section{HASIL PENELITIAN DAN PEMBAHASAN}

Konsep neuropedagogi merupakan topik yang sudah cukup lama diperbincangkan, dalam artikel ini ditelaah tren penelitian neuropedagogi antara tahun 2015 hingga tahun 2019. Pada tahun 2015, Silva Lopez dkk melakukan pengembangan pembelajaran berbasis neuropedagogi yang dikenal dengan Techno Neuro Pedagogy System (TNPS), yaitu suatu sistem yang terdiri dari 8 fase: analisis, desain, pengembangan, pengujian, implementasi, dokumentasi, pemeliharaan, dan evaluasi. TNPS tergabung dalam model siklus hidup perangkat lunak tambahan dan pengembangan iteratif yang merupakan bagian penting dari rekayasa perangkat lunak. TNPS mengintegrasikan pendidikan, Nurosains, dan teknologi dimensi, yang 
memfasilitasi pengembangan profil kognitif siswa agar dapat menyesuaikan kegiatan pembelajarannya. Penelitian eksperimen ini melibatkan 752 mahasiswa dari 10 Program sarjana teknik di Meksiko. Hasil penelitian menunjukkan bahwa dengan menerapkan metodologi TNPS selama Pemrograman Terstruktur selama 4 kuartal berturut-turut menunjukkan bahwa selama fase inisiasi, pembobotan gaya berpikir selama akuartal 12-Q tidak meningkat secara signifikan. Namun,saat iterasi, diusulkan oleh TNPS diterapkan interative-incremental metodologi, rincian prototipe disempurnakan menyebabkan dampak positif pada bobot secara berturutturut pada kuartal berikutnya. Berdasarkan hasil yang diperoleh dari temuan, bahwa aplikasi TNPS sebagai model pembelajaran desain dalam kursus serta teknologi informasi digunakan telah meningkatkan bobot gaya berpikir mereka, diharapkan akan dikembangkan oleh mahasiswa selama pemrograman kursus terstruktur.

Pada tahun berikutnya, yakni tahun 2017 riset tulisan mengenai neuropedagogi didominasi oleh artikel dengan metode literature review seperti yang dilakukan oleh Moravcová \& Mad'arová (2016), mereka menjelaskan konsep neurodidactic dan pemanfaatannya dalam pembelajaran bahasa asing. Temuan penelitian menunjukkan bahwa menguasai satu dan lebih bahasa asing saat ini dianggap sebagai salah satu prasyarat utama dalam kehidupan setiap orang muda untuk mendapatkan pekerjaan dan membangun diri sebagai seorang ahli dalam pekerjaan. Tugas ini harus dipenuhi oleh sekolah, kecuali jika seseorang memiliki kesempatan untuk belajar lebih banyak bahasa di lingkungan asalnya. Pendidikan bahasa asing wajib tergantung pada keadaan negara tertentu. Model pengajaran tradisional 'seorang guru - sebuah buku pelajaran - seorang siswa' secara bertahap diganti oleh beberapa metode yang lebih baru. Interdisiplin lain tercatat di bidang pendidikan pada tahun 1980-an , yang dikenal sebagai neurodidactics.
Neuropedagogi dan neurodidaktik lebih dipopulerkan saat ini dan oleh banyak orang dianggap sebagai revolusi dalam pendidikan. Penemuan neurosains juga berarti pandangan baru tentang pendidikan, kepribadian pelajar, atau motivasi untuk belajar bahasa asing dan untuk memperoleh kompetensi bahasa asing.

Nouri (2016), melakukan review untuk mengumpulkan kontribusi dari bidang pendidikan, psikologi, ilmu kognitif, dan tentu saja, neurosains itu sendiri untuk memperkenalkan prinsipprinsip dasar penelitian di bidang studi neurosains. Penelitian neuroedukasi dapat dipahami sebagai upaya interdisipliner untuk mengembangkan pemahaman yang mendalam dan gambaran holistik masalah yang berkaitan dengan pembelajaran dan pendidikan. Dengan demikian secara epistemologis didasarkan pada paradigma pluralisme metodologis yang terintegrasi. Ini menuntut para peneliti untuk memahami berbagai metode dan metodologi dan menggunakan ketika mereka merumuskan proyek penelitian mereka sendiri. Para peneliti memiliki peran penting untuk dimainkan dalam menyediakan bukti dan kesimpulan sistematis yang valid secara ilmiah dan dapat diandalkan serta relevan secara pendidikan dan bermanfaat. Salah satu implikasi signifikan dari argumen ini adalah kebutuhan untuk memperkuat kualitas komponen penelitian dalam program pascasarjana bidang ini dan melatih peneliti yang tertarik dalam identifikasi dan perumusan pertanyaan penelitian yang relevan. Dilengkapi oleh Stepanov dkk (2016) telah menelaah konsep neuropedagogi sebagai pembangunan fase modern dalam Ilmu Pendidikan. Temuannya menunjukkan bahwa banyak pengetahuan baru yang signifikan diperoleh dari neurosains pada kemampuan berbahasa manusia dan berbicara, komunikasi pribadi dan transpersonal antara orang-orang, tidak hanya pada aktivitas saraf yang lebih tinggi (kemampuan reflektif), tetapi pada aktivitas saraf yang lebih rendah juga (untuk otak 
yang holistik dan sistematis dan kontrol tubuh manusia). Banyak masalah lain yang pantas mendapatkan diskusi khusus oleh para pendidik dan orang tua.

Pada tahun 2016 juga, seorang peneliti bernama Kirby (2016) melalui penelitian kualitatifnya yang bertujuan untuk berbagi catatan, sejarah pribadi seorang pendidik mengejar minat dalam pengetahuan otak. Selama kurang lebuih 40 tahun, daya tarik ini memicu gagasan untuk membuat kursus bagi para guru berbasis neurosains. Tugas kursus tertentu akan membutuhkan guru untuk menafsirkan pengetahuan tentang otak dalam konteks kelas masing-masing. Temuannya menunjukkan bahwa tiga pengamatan menyeluruh muncul dari tahun-tahun studi ini. Pertama, guru mencari perspektif baru yang membantu mereka menafsirkan apa yang terjadi di ruang kelas mereka. Kedua, pengetahuan tentang neurosains mengubah keyakinan guru dan perilaku mereka di kelas. Ketiga, para guru berterima kasih berterima kasih atas informasi neurosains dan berharap memiliki pengetahuan seperti itu secara positif akan mempengaruhi lingkungan belajar di kelas mereka. Dari pengalaman bertahun-tahun, ia melihat tiga implikasi utama. Pertama, ilmu otak memberikan yang bahasa berbeda dan jendela, untuk memahami apa yang menjadi ruang lingkup guru - apa yang terjadi diruang kelas mereka. Kedua, guru menemukan ilmu neurosains bermanfaat dan dapat mengembangkan banyak strategi untuk setiap konsep neurosains. Akhirnya, pendidikan sekolah, dan pendidikan guru pada umumnya, perlu memasukkan pekerjaan kursus neurosains dalam program pendidikan guru mereka. Berdasarkan literatur yang ditinjau, penelitian neuroedukasi dapat dipahami sebagai upaya interdisipliner untuk mengembangkan pemahaman yang mendalam dan gambaran holistik masalah yang berkaitan dengan pembelajaran dan pendidikan. Dengan demikian secara epistemologis didasarkan pada paradigma pluralisme metodologis yang terintegrasi.
Ini menuntut para peneliti untuk memahami berbagai metode dan metodologi dan menggunakan ketika mereka merumuskan proyek penelitian mereka sendiri. Para peneliti memiliki peran penting untuk dimainkan dalam menyediakan bukti dan kesimpulan sistematis yang valid secara ilmiah dan dapat diandalkan serta relevan secara pendidikan dan bermanfaat. Salah satu implikasi signifikan dari argumen ini adalah kebutuhan untuk memperkuat kualitas komponen penelitian dalam program pascasarjana bidang ini dan melatih peneliti yang tertarik dalam identifikasi dan perumusan pertanyaan penelitian yang relevan.

Schmidt, Pallesen, \& Kaae Kristensen, (2016) juga melalui penelitian kualitatifnya menghasilkan pengetahuan baru tentang inisiatif pedagogis dan kerangka kerja yang terlibat dalam partisipasi dan kegiatan anak-anak dengan Acquired Brain Injury (ABI), semuanya berusia antara 10 dan 12 tahun selama proses Constraint-Induced Movement Therapy (CIMT). Hasilnya menunjukkan bahwa pendekatan dan kerangka kerja pedagogis memiliki pengaruh penting pada kegiatan, partisipasi, dan motivasi anakanak yang berpartisipasi di seluruh intervensi CIMT. Faktor-faktor kunci termasuk individualisasi dengan adaptasi, kompensasi, perhatian dan pelatihan tujuan spesifik. Struktur perusahaan dan, pada saat yang sama, beragam kegiatan di semua domain International Classification of Functioning (ICF) sangat penting untuk mencapai hasil yang sukses dalam intervensi CIMT. Studi saat ini juga menunjukkan bahwa partisipan anak-anak dengan ABI meningkatkan keterampilan fungsional mereka setelah 2 minggu intervensi CIMT. Hasil utama dari analisis struktural dan hasil sekunder yang diukur dengan skor fungsional dari tiga instrumen saling melengkapi dengan menunjukkan peningkatan kekuatan, ketangkasan dan fungsi. Pola lain yang diamati meliputi penggunaan fungsional spontan tungkai atas terganggu dan keterlibatan bimanual 
alami, yang menunjukkan pengaruh positif intervensi CIMT pada mendapatkan kembali keterlibatan alami tungkai atas terganggu setelah ABI.

$$
\text { Tahun 2017, penelitian }
$$
neuropedagogi masih berkisar seputar review yang salah satunya dilaukan oleh Caragea dkk (2017), dalam tulisannya mereka mencoba mengeksplorasi sejarah singkat bidang neuropedagogi, untuk mendefinisikan batas kedisiplinan dan hubungannya dengan domain lain seperti psikologi pendidikan atau neurosains, dan untuk mengidentifikasi kontribusinya yang potensial terhadap teori dan praktik pendidikan. Temuannya mengundikasikan bahwa ketika mempertimbangkan penerapan pengetahuan baru tentang neuropedagogi langsung ke praktik pendidikan, kita juga harus mempertimbangkan beberapa aspek. Pertama, pendidikan perlu memastikan keamanan para siswa karena begitu banyak masalah etika berasal dari neurosains ini. Kedua, guru dan profesional pendidikan lainnya terlibat harus dilatih untuk lebih memahami implikasi dari pengetahuan baru yang ingin mereka terapkan terhadap pendidikan. Apalagi para ahli berasal dari luar pendidikan dan tertarik mengembangkan proyek penelitian neuropedagogi, harus mempertimbangkan ketertarikan dalam pendidikan dan merkea membutuhkan tim ahli untuk memberikan masukan yang baik dan mendalam untuk proyek mereka. Mercier \& Bédard (2017) juga melalukan review untuk mengkaji masalah dalam penelitian terkait bimbingan belajar saat ini, yaitu interaksi granularitas dan dampaknya pada pembelajaran, dan untuk menyarankan bahwa perspektif pendidikan neurosains dapat berkontribusi untuk mengkarakterisasi dan meningkatkan interaksi bimbingan belajar. Perspektif ini menyoroti hipotesis bahwa kelangkaan informasi yang dapat diakses oleh tutor dan tutee selama interaksi alami mengarah pada interaksi pembelajaran yang tidak optimal. Sebagai tanggapan potensial terhadap kurangnya informasi ini, dikatakan bahwa metodologi dari kognitif dan neurosains dapat memberikan informasi terkait selama atau setelah interaksi pembelajaran, dan bahwa informasi ini dapat secara signifikan memberdayakan siswa dan tutor. Penelitian empiris yang diproyeksikan dapat mengarah pada reinterpretasi dramatis dari 35 tahun penelitian les yang sudah berhasil.

Tahun 2018 sepertinya menjadi puncak emas penelitian neuropedagogi, hal ini ditandai dengan banyaknya tulisan yang terbit terkait bidang ini. Diantaranya yang ditulis oleh Szécsi, Varga, \& Mak (2018) melalui analisis isi terhadap pemikiran Nouri (2016), mengidentifikasi lima prinsip untuk penyelidikan ilmiah dalam neuropedagogi: Pertama, pendidikan neuro bersifat interdisipliner karena peneliti memasukkan pengetahuan dari berbagai bidang yang meliputi psikologis, neurosains dan pedagogis fondasi pembelajaran dan pengembangan. Kedua penelitian neuroedukasi menggambarkannya sebagai penelitian terapan yang pada akhirnya menghasilkan temuan yang meningkatkan praktik pendidikan. Pada akhirnya, pendidik dan ilmuwan didorong untuk berkolaborasi dan mengidentifikasi dan memeriksa pertanyaan yang akan memajukan praktik pendidikan. Ketiga penelitian neuroedukasi dapat menggunakan berbagai desain metodologis; dengan demikian keduanya metode kualitatif dan kuantitatif dapat menawarkan tingkat pemahaman baru terkait pembelajaran dan pengembangan. Keempat adalah ekspektasi berkenaan dengan kemampuan peneliti, sesuaikan penelitian neuroedukasi dan sudut pandang filosofis mereka sendiri. Secara khusus, Peneliti dengan orientasi filosofis tertentu menentukan pertanyaan dan masalah apa yang selidiki. Kelima terakhirnya adalah pendidikan neuro itu jenuh-nilai karena masalah etika dan moral yang terlibat. Mak, Szécsi \& Varga (2018) melalui temuannya terhadap review neuropedagogi di bidang pendidikan anak usia dini. Dalam penelitiannya dikemukakan bahwa bidang neuropedagogi sedang dalam tahun-tahun 
awal pengembangannya. Karena relevansi kunci perkembangan otak anak usia dini, penting untuk melakukan penelitian dengan teknologi pencitraan otak. Oleh karena itu, sangat penting untuk melanjutkan pertumbuhan bidang studi ini dengan desain studi metodologi yang solid, kesimpulan hasil yang masuk akal, dan untuk membuat studi yang dapat direproduksi. Sebagai tinjauan studi menunjukkan sistem teknologi EEG portabel memungkinkan untuk pengumpulan data berkualitas tinggi yang dapat dicapai untuk laboratorium penelitian dengan sumber daya terbatas. Tambahan penelitian yang unik dan tak ternilai ini memungkinkan lebih banyak data dikumpulkan dan dianalisis berdasarkan temuan terbaru. Neuropedagogi adalah bidang yang menjanjikan untuk mengembangkan pemahaman otak yang sedang berkembang. Feiler \& Stabio (2018) mengemukakan temuan dari sistematic literature review yang dilakukannya terkait neuropedagogi. Penelitian mereka mengungkapkan bahwa bidang pendidikan neurosains selama 30 tahun terakhir telah ditentukan oleh tiga tema utama yang meliputi aplikasi, kolaborasi antar disiplin ilmu, dan terjemahan bahasa. Tema-tema ini telah berfungsi sebagai pilar dasar untuk lapangan dan mendukung pertumbuhannya di masa depan. Pendidikan neurosains seharusnya tidak menggantikan disiplin ilmu yang berhubungan dengan psikologi atau bahkan disiplin ilmu yang berhubungan dengan neurosains, tetapi harus, sebaliknya, berdiri di atas pundak para raksasa ini dan menambahkannya dengan menggunakan teknologi dan metodologi canggih yang ditawarkan oleh neurosains untuk mengeksplorasi dan memahami otak. Yang penting, perlu ditekankan bahwa pendidikan neurosains berupaya membantu siswa - tujuannya harus mendorong siswa untuk memahami cara belajar mereka yang terbaik sehingga meminimalkan kesulitan yang tidak seimbang di kelas dan untuk mempromosikan pencapaian sepanjang hidup. Chojak (2018) menyatakan bahwa neuropedagogi memiliki potensi untuk menjadi disiplin ilmu independen, yang dapat memberikan informasi misalnya tentang ancaman dan kemungkinan digitalisasi proses pendidikan, efisiensi berbagai inovasi pedagogis (metode atau program pengajaran) atau program terapeutik. Pedagog dapat memperoleh kemungkinan untuk mengkonfirmasi atau menolak tesis yang diadopsi secara obyektif dan andal. Dalam kasus disiplin yang baru terbentuk pada abad ke-17 dan masih terus berevolusi, ini adalah kesempatan untuk pengembangan yang lebih intensif. Varga \& Szécsi (2018) dengan penelitian surveynya terhadap 45 guru yang berusia antara 35-46 tahun berasal dari 10 TK untuk mengeksplorasi pengetahuan guru anak usia dini tentang perkembangan otak dan kesediaan mereka untuk mengeksplorasi dan menggunakan temuan terbaru dari studi neurosains. Hasilnya bahwa mayoritas guru $(75 \%)$ memiliki pengetahuan dasar tentang teori terkait dengan perkembangan neurologis anak-anak. Sebagian besar peserta (86\%) menyatakan minat, dan kemauan untuk memperluas pengetahuan mereka tentang implikasi studi neuropedagogi. Bahkan persentase guru yang lebih tinggi $(91 \%)$ percaya bahwa mereka akan membutuhkan pengembangan yang lebih profesional dalam metode dan pendekatan yang kondusif dan selaras dengan perkembangan otak. Aleksandrova dkk (2018) dalam penelitian Research and development mengembangkan proyek inovatif pada penggunaan antarmuka saraf "NeuroFocus" dan robot antropomorfik dalam pendidikan akan diuji di lembaga pendidikan kota dan wilayah dalam perjalanan bekerja dengan berbagai kategori siswa. Diharapkan bahwa metode yang menggunakan teknik umpan balik biologis melalui analisis sinyal EEG, akan memperjelas keadaan emosional dan psikologis siswa penyandang disabilitas, fokus perhatiannya, dan, akibatnya, untuk menentukan strategi dalam konteks perluasan keterampilan. sosial. Diharapkan 
bahwa hasil proyek dapat digunakan tidak hanya di bidang pendidikan sekolah. Metode yang dikembangkan yang menyediakan pembentukan fleksibel dan pemutaran skenario stimulasi kognitif menggunakan stimulus seperti gambar, file suara, dan informasi tanda-alfabet, serta inklusi dalam proses pendidikan asisten robot tipe antropomorfik akan menemukan aplikasi di tingkat pendidikan lainnya (prasekolah, umum dasar, sekunder, lebih tinggi, tambahan, termasuk profesional), dengan mempertimbangkan kebutuhan mendesak mereka, dan dapat berfungsi sebagai salah satu faktor integrasi dan pada saat yang sama mengoptimalkan sistem pendidikan di Rusia. Aleksandrova, Hramov \& Khramova (2018) melakukan penelitian yang melibatkan 59 anak berusia 7-8 tahun (Inggris, waktu percobaan - 3 tahun). Semua anak belajar di sekolah dasar yang sama, tetapi dibagi menjadi dua kelas. Dasar teknis terdiri dari: layar sentuh (Sandtray), robot humanoid Nao, ekstrusi bingkai aluminium dan alat perekam. Hasil penelitiannya menghasilkan beberapa hal antara lain: Penting untuk memahami perilaku adaptif individu mana yang mengarah ke dampak positif pada pengguna, atau mana dari mereka yang mengarah ke keterikatan dalam berbagai konteks; Indikator yang diperlukan untuk evaluasi sistem adaptif harus diselidiki secara menyeluruh. Ada kebutuhan untuk pengembangan protokol penelitian karena akan membantu para peneliti untuk secara sistematis membandingkan hasil dengan sebelumnya. Sistem adaptif mengubah perilakunya berdasarkan perilaku pengguna, sehingga harus dievaluasi dalam interaksi jangka panjang, untuk memastikan potensinya; Robot adaptif perlu menyimpan informasi tentang pola interaksi pengguna. Oleh karena itu, privasi data adalah salah satu masalah yang perlu dipertimbangkan. Kita perlu mendefinisikan pedoman yang akan dapat mendukung pertimbangan etis dan menunjukkan data yang harus disimpan oleh robot dan berpotensi digunakan, terutama dalam kasus di mana kelompok pengguna adalah anak perusahaan; Masalah yang lain terletak pada pemahaman yang dapat diterima, karena kelompok pengguna tertentu yang diperlukan dapat diterima dari robot. Jadi, kita juga perlu membahas pertanyaan tentang interaksi pengguna saat berinteraksi dengan robot.

Doukakis \& Vlamos (2018) melakukan penelitian terhadap mahasiswa teknik pemrograman melalui pendekatan neuropedagogi, temuannya menunjukkan bahwa perkembangan teknik pencitraan otak seperti elektroensefalografi dan pencitraan resonansi magnetik fungsional baru-baru ini, telah memberikan peluang tambahan bagi ahli saraf untuk mengeksplorasi organisasi fungsional otak manusia. Dengan menggunakan teknikteknik ini, penelitian ini merupakan pendekatan untuk mendukung pembelajaran di bidang pembelajaran dan pengajaran pemrograman komputer. Di satu sisi, ada upaya untuk menghubungkan ilmu saraf teoretis dengan ilmu kognitif; di sisi lain, data penelitian yang diperoleh akan berkontribusi pada identifikasi praktik yang dapat diterapkan pada pendidikan pemrograman formal dan informal. Coutts \& Davis (2018), dalam risetnya mengkaji perlunya lembaga pendidikan tinggi, pendidik dan pemerintah untuk mengenali dan memahami lebih komprehensif kompleksitas kerentanan pelajar yang beragam. Kebijakan dan praktik pendidikan inklusif, yang mengakui dan mendukung 'siswa yang berisiko', harus dilengkapi dengan pelatihan guru yang komprehensif. dalam gaya belajar yang beragam. Dalam konteks a self-study action research (SSAR), proses pengembangan kolaboratif bertujuan untuk meningkatkan praktik dan memberdayakan rekan peneliti dan peneliti. Diskusi utama difokuskan pada co-peneliti; Namun, tertanam di seluruh makalah ini adalah contoh dari perbaikan peneliti dan refleksi pada praktik. Paling penting adalah konteks sosial budaya bersama; perubahan pola komunikasi; memahami konsepkonsep baru; penggunaan metode kreatif 
yang proaktif; dan akomodasi yang mendukung masalah emosional dalam kompleksitas pengalaman hidup dari disleksia dan masalah kesehatan kronis.

Allaberdieva (2019) dalam artikel yang berjudul The Main Neuropedagogic Possibilities Of Formation At Children Of Senior Preschool Age Of Creative Activity menyebutkan bahwa kehidupan modern menuntut teknologi pedagogis untuk anakanak usia 4-7 pengetahuan kualitatif yang mendalam, menciptakan basis intelektual untuk pelatihan selanjutnya, dan, di sisi lain, dibimbing oleh kesehatan fisik, mental, spiritual anak dan untuk mempertimbangkan kemungkinan neuropedagogis dari usia yang diberikan. Mereka mengikuti:1) dialog yang luas, termasuk dengan orang dewasa yang kreatif; 2) lingkungan orang dewasa bertindak sebagai sampel untuk imitasi; 3) gaya demokratis hubungan timbal balik antara orang tua dan anak-anak; 4) izin untuk ekspresi diri emosional anak; 5) aktif, posisi aktif orang dewasa; 6) sebelumnya membiasakan anak dengan pekerjaan independen; 7) membiasakan diri dengan kreativitas melalui kunjungan berbagai kalangan; 8) membiasakan diri dengan kesenangan pengetahuan melalui pengalaman sendiri, 9) hubungan positif dengan aktivitas penelitian anak; 10) pengembanganberpikir kreatif. Sandakova \& Tolstobrova (2019) dalam review tentang proliferasi neurosains dalam pedagogi dan pendidikan, menyatakan bahwa proliferasi ilmu saraf dalam pedagogi dan sistem pendidikan diimplementasikan pada dua tingkatan: dalam paradigma humanistik dan teknokratis. Paradigma humanistik terhubung dengan gagasan seseorang sebagai sistem pengembangan diri biososiologis yang kompleks. Kemampuan yang sesuai dari neuro-pedagogi terdiri dalam pemahaman yang lebih dalam dan lebih kompleks dari proses fungsi dan pengembangan jiwa dalam ontogenesis, serta dalam pengembangan sarana untuk individualisasi interaksi pedagogis. Paradigma teknokratis memungkinkan pengurangan pedagogi ke teknologi pengelolaan pembentukan dan pengembangan sistem kognitif. Kompleksitas kodrat manusia diratakan. Signifikansi untuk parameter "teknis" perbaikan manusia adalah hipertrofi. Kemungkinan baru untuk memanipulasi seseorang dan minatnya terbuka. Neuropedagogi, diangkat ke peringkat teknologi sosial melalui penyederhanaan dan komersialisasi ide dan metode, kehilangan potensi humanistiknya dan sering diartikan sebagai pengenalan teknologi neuroteknologi ke dalam proses pendidikan. Neuroscience adalah proyek sosial-ekonomi modern, yang melibatkan 5 kemungkinan arahan untuk implementasi: 1) pelatihan spesialis dalam teknologi neuroteknologi; 2) mempopulerkan pengetahuan yang diperoleh dalam penelitian inovatif dalam neurobiologi; 3) pengenalan teknologi neuroteknologi sebagai didaktik, teknik adaptasi, cara teknis, dan teknologi perangkat saraf dalam proses pendidikan; 4) proyek bisnis yang menggunakan efek kebaruan untuk membentuk sektor pasar baru; 5) proyek masa depan Transhumanist. Doukakis (2019) melengkapi riset pedagogi dengan mengeksplorasi kemungkinan perbedaan dalam aktivitas otak delapan siswa ilmu komputer dengan metode electroencephalogram (EEG) dalam perkuliahan pemrograman. Menurut analisis data, tampaknya jenis bahasa pemrograman tidak mempengaruhi aktivitas otak siswa. Juga, enam siswa membutuhkan lebih banyak waktu untuk berhasil mengembangkan programprogram yang mereka tanyakan dengan bahasa pemrograman pertama versus yang kedua, terlepas dari jenis bahasa pemrograman yang pertama. Selain itu, tampak bahwa enam siswa tidak menunjukkan pengurangan atau peningkatan aktivitas otak saat mereka menghabiskan waktu untuk tugas-tugas dan pada saat yang sama tidak menunjukkan pengurangan atau peningkatan dalam waktu yang mereka butuhkan untuk 
mengembangkan program. Akhirnya, para siswa menunjukkan aktivitas otak rata-rata yang lebih tinggi dalam pengembangan tugas keempat daripada yang ketiga, dan enam dari mereka menunjukkan aktivitas otak rata-rata yang lebih tinggi ketika mengembangkan program pertama versus kedua, terlepas dari bahasa pemrograman. Hasilnya dapat berkontribusi untuk: a) menyoroti perlunya pendekatan pendidikan yang beragam bagi siswa ketika terlibat dalam pengembangan program dan $b$ ) mengidentifikasi jalur pembelajaran yang tepat untuk meningkatkan pendidikan siswa dalam pemrograman.

\section{KESIMPULAN}

Penelitian mengenai neuropedagogi telah mengalami perkembangan yang cukup signifikan, berbagai bidang keilmuan telah berupaya mengintegrasikan neuropedagogi sebagai sebuah pendekatan, teknik dan metode pembelajaran guna mengoptimalkan performa peserta didik dalam belajar. Berbagai jenjang pendidikan dimulai tingkat pendidikan usia dini hingga mahasiswa telah menjadi sasaran pendekatan neuropedagogi, namun penelitian tentang implementasi neuropedagogi pada jenjang sekolah dasar belum banyak diteliti. Hal inilah yang mendasari penulis untuk melakukan review terhadap trend penelitian neuropedagogi, agar menjadi rekomendasi tindak lanjut penelitian berikutnya, khususnya di bidang pendidikan dasar.

\section{DAFTAR PUSTAKA}

Aleksandrova, N. A., Chernyaeva, T. N., Khramova, M. V., \& Hramov, A. E. (2018, September). The Implementation Of The Innovation Platform" Educational Potential Of Hardware-Software Complexes Based On The Study And Interpretation Of Brain Activity Patterns". In 2018 IEEE International Conference" Quality Management, Transport And Information Security, Information
Technologies" $(I T \& Q M \& I S) \quad(\mathrm{Pp}$. 533-535). IEEE.

Aleksandrova, N. A., Hramov, A. E., \& Khramova, M. V. (2018, September). Designing, Implementation And Use Of Robotic Devices In The Social Sectors In Foreign Studies. In 2018 IEEE International Conference" Quality Management, Transport And Information Security, Information Technologies" $(I T \& Q M \& I S) \quad$ (Pp. 536-541). IEEE.

Allaberdieva, K. (2019). The Main Neuropedagogic Possibilities Of Formation At Children Of Senior Preschool Age Of Creative Activity. European Journal Of Research And Reflection In Educational Sciences Vol, 7(12).

Bergen, D., \& Woodin, M. (2017). Brain Research And Childhood Education. Implications For Educators, Parents And Society. New York: Routledge.

Caragea, V. M., Miulescu, M. L., Balica, M., \& Voinea, L. (2017). Educational Neuroscience: The Rise Of A New Research Field In Educational Sciences. Ukrainian Pedagogical Journal, 3, 89-101.

Chojak, M. (2018) Neuropedagogy As A Scientific Discipline: Interdisciplinary Description Of The Theoretical Basis For The Development Of A Research Field.World Academy of Science, Engineering And Technology International Journal Of Educational And Pedagogical Sciences, Vol. 12 (8)

Coutts, K. D. R., \& Davis, K. (2018). Diverse Learning And The Challenge Of Inclusive Practices In Higher Education: An Australian Self-Study Action Research Exemplar Of A Student With Dyslexia.

Doukakis, S., \& Vlamos, P. (2018). Enhancement Programming Skills And Transforming Knowledge Of Programming

Through 
Neuroeducation

Approaches. Education, 4(12).

Doukakis, S. (2019). Exploring Brain Activity And Transforming Knowledge In Visual And Textual Programming Using Neuroeducation Approaches.

Feiler, J. B., \& Stabio, M. E. (2018). Three Pillars Of Educational Neuroscience From Three Decades Of Literature. Trends In Neuroscience And Education, 13, 17-25.

Kirby, L. F. (2016). Brain Science And Teaching: A Forty-Year Personal History. In Forum On Public Policy Online (Vol. 2016, No. 1). Oxford Round Table. 406 West Florida Avenue, Urbana, IL 61801.

Kitchenham, B., \& Charters, S. (2007). Guidelines For Performing Systematic Literature Reviews In Software Engineering.

Mak, V., Szécsi, T., \& Varga, L. (2018). Overview Of EEG Research In Early Childhood Education: An International Perspective. Képzés És Gyakorlat: Training And Practice, 16(3), 37-44.

Mercier, J., \& Bédard, M. (2017). An Educational Neuroscience Perspective On Tutoring: To What Extent Can Electrophysiological Measures Improve The Contingency Of Tutor Scaffolding And Feedback?. Themes In Science And Technology Education, 9(2), 109125.

Moravcová, L., \& Mad’arová, L. (2016). Neurodidactics And Its Utilization In The Field Of Language Teaching. $W$ E. Horská, Z. Kapsdorferová, M. Hallová (Red.), International Scientific Days.

Nouri, A. (2016). The Basic Principles of Research in Neuroeducational Studies. International Journal of Cognitive Research In Science, Engineering And Education. 4(1)
Schmidt., Pallesen, H., \& Kaae Kristensen, H. (2016). Constraint-Induced Movement Therapy For Children With Acquired Brain Injury: Didactical Approach And Functional Change. European Journal of Physiotherapy, 18(1), 34-46.

Sandakova, L. B., \& Tolstobrova, L. I. (2019, July). Proliferation Of Neuroscientific Knowledge In Pedagogy And Education. In " Humanities And Social Sciences: Novations, Problems, Prospects"(HSSNPP 2019). Atlantis Press.

Silva-López, R. B., Fallad, J., Reyes-Ortiz, J. A., Bravo, M., \& Rodriguez, J. (2015, December). Techno Neuro Pedagogy System: An Instructional Design Methodology For Customized Online Courses (Virtual Customized Environment Learning). In 2015 International Conference On Computational Science And Computational Intelligence (CSCI) (Pp. 281-286). IEEE.

Stepanov, V., Levanova, E., Klemantovich, I., \& Kozilova, L. (2016). Neuropedagogics As The Modern Phase Of The Development Of The Education Science. YOUNG SCIENTIST (USA), Vol. 6, 25.

Szécsi, T., Varga, L., \& Mak, V. (2018). Current Trends, Dilemmas And Future Directions In Neuropedagogy In The Field Of Early Childhood. Képzés És Gyakorlat: Training And Practice, 16(3), 51-58.

Varga, L., \& Szécsi, T. (2018). Neuropedagogy In Early Childhood In Hungary: Foundations And MicroInvestigation. Képzés És Gyakorlat: Training And Practice, 16(3), 67-74. 